\title{
Differential autumn migration of the aquatic warbler Acrocephalus paludicola
}

\author{
Katarzyna Wojczulanis-Jakubas • Dariusz Jakubas • \\ Julien Foucher • Joanna Dziarska-Pałac • Hubert Dugué
}

Received: 18 February 2013 /Revised: 10 October 2013 / Accepted: 11 October 2013 /Published online: 24 October 2013

(C) The Author(s) 2013. This article is published with open access at Springerlink.com

\begin{abstract}
Relatively little attention has been paid to sex differences in the migration of birds in autumn. We studied the autumn migration strategy of molecularly sexed males and females in the globally threatened aquatic warbler Acrocephalus paludicola. We captured 176 birds at a stopover site in the Loire estuary at Donges, France. The median date for the passage of adults was 8 days earlier in males than females, although the timing of migration in first-year males and females was similar. This indicates that males, who are without parental duties, can start their migration earlier than females and first-year birds. Adults were significantly heavier than immature birds but did not have higher fat scores. In both age categories, more males (two to three times more) were captured. However, various factors (including tape-luring) can affect observed sex ratio.
\end{abstract}

Keywords Autumn migration · Differential migration Sex differences

Communicated by: Pamela Rasmussen

K. Wojczulanis-Jakubas $(\bowtie) \cdot$ D. Jakubas

Department of Vertebrate Ecology and Zoology, University of

Gdańsk, ul. Wita Stwosza 59, 80-308 Gdańsk, Poland

e-mail: biokwj@univ.gda.pl

J. Foucher $\cdot$ J. Dziarska-Pałac $\cdot$ H. Dugué

Association pour la Connaissance et la Recherche Ornithologique

Loire et Atlantique (ACROLA), La Jannais des Douets,

44360 Cordemais, France

J. Dziarska-Pałac

Department of Nature Conservation, Maria Curie-Sklodowska

University, Faculty of Biology and Biochemistry,

ul. Akademicka 19, 20-033 Lublin, Poland

\section{Introduction}

Differential migration in males and females has been demonstrated in various bird species (Cristol et al. 1999). It has been extensively studied, in relation to spring migration, that when selection favours earlier arrivals of a given sex (usually males) at the breeding grounds, due to competition for high-quality territories and mates (Kokko 1999). Much less attention has been paid to differential migration in the autumn, although passage to the wintering grounds may also be timeconstrained in a different manner for the two sexes.

We investigated the autumn passage of molecularly sexed male and female aquatic warblers Acrocephalus paludicola, with regard to their age and body condition. The aquatic warbler is a globally threatened passerine; its population size and range have decreased by $90 \%$ over the last century (Flade and Lachmann 2008). During autumn, the birds migrate to a tropical sub-Saharan African location (Buchanan et al. 2011; Flade et al. 2011; Foucher et al. 2013; Salewski et al. 2013) through western (de By 1990; Aquatic Warbler Conservation Team 1999) and possibly southern Europe (Salewski et al. 2013).

Earlier studies of the aquatic warbler's autumn migration based on small samples did not examine sex differences (de By 1990; Atienza et al. 2001; Julliard et al. 2006; Miguélez et al. 2009; Neto et al. 2010; Le Nevé et al. 2011). However, in view of the breeding biology of the species - only the female provides care for the offspring; the male is free of parental duties after the mating period (Dyrcz et al. 2002) - a differential pattern may be expected. One might also expect that the two-peak pattern of autumn migration (Neto et al. 2010; Le Nevé et al. 2011) would relate to sex differences in the timing of migration. 


\section{Material and methods}

This study was carried out at Donges on the Loire estuary $\left(47^{\circ} 18^{\prime} 17.19^{\prime \prime} \mathrm{N}, 2^{\circ} 2^{\prime} 9.51^{\prime \prime} \mathrm{W}\right)$, one of the most important sites in France for capturing the aquatic warbler (Le Nevé et al. 2011). We performed the fieldwork in 2011, covering the entire autumn migration period of adult aquatic warblers and almost the entire migration period for young birds in this area (18 July-15 September; Le Nevé et al. 2011). We captured the birds in 25 mist-nets placed in the reedbed habitat, opened just before local sunrise for circa $6 \mathrm{~h}$ (weather permitting). We used tape-luring for the whole capturing period (played from about $1 \mathrm{~h}$ before local sunrise until the nets were closed). We ringed and aged the captured birds by external characteristics (Svensson 1992). We measured the right wing with a ruler $( \pm 0.5 \mathrm{~mm})$ to provide a surrogate measure of body size and body mass using an electronic scale ( $\pm 0.1 \mathrm{~g}$, My Weigh PointScale 5.0). We determined the fat score according to the 4-score scale proposed by the French ringing centre, CRBPO-Muséum Paris.
We took 1-5 body feathers from each bird for molecular sexing, including the primer pair P2 and P8 (according to the method of Griffiths et al. 1998). We extracted DNA from the proximal tip of feathers using the Sherlock AX kit for biological tracks (A\&A Biotechnology, Gdynia, Poland). We sampled 176 of $179(98 \%)$ birds captured during the whole study period, sexing all of them successfully. We have not included the retrap records in the analyses.

\section{Results}

The median capture dates for different sex and age groups ranged from 11 to 20 August (Fig. 1). In adults, the timing of migration differed between sexes (MannWhitney $U$ test, $Z_{29,13}=-3.73, P<0.001$ ), with the median date for males being 8 days earlier than for females (Fig. 1). Immature males and females migrated at a similar time $\left(Z_{99,35}=-1.30, P=0.19\right)$, with only a 1 -day difference between median dates (Fig. 1). Adult males migrated earlier than immature males (9-day difference in the
Fig. 1 Timing of autumn migration in aquatic warblers grouped by ages and sex at a stopover site in the Loire estuary (Donges, France). Numbers in brackets denote the relevant sample size
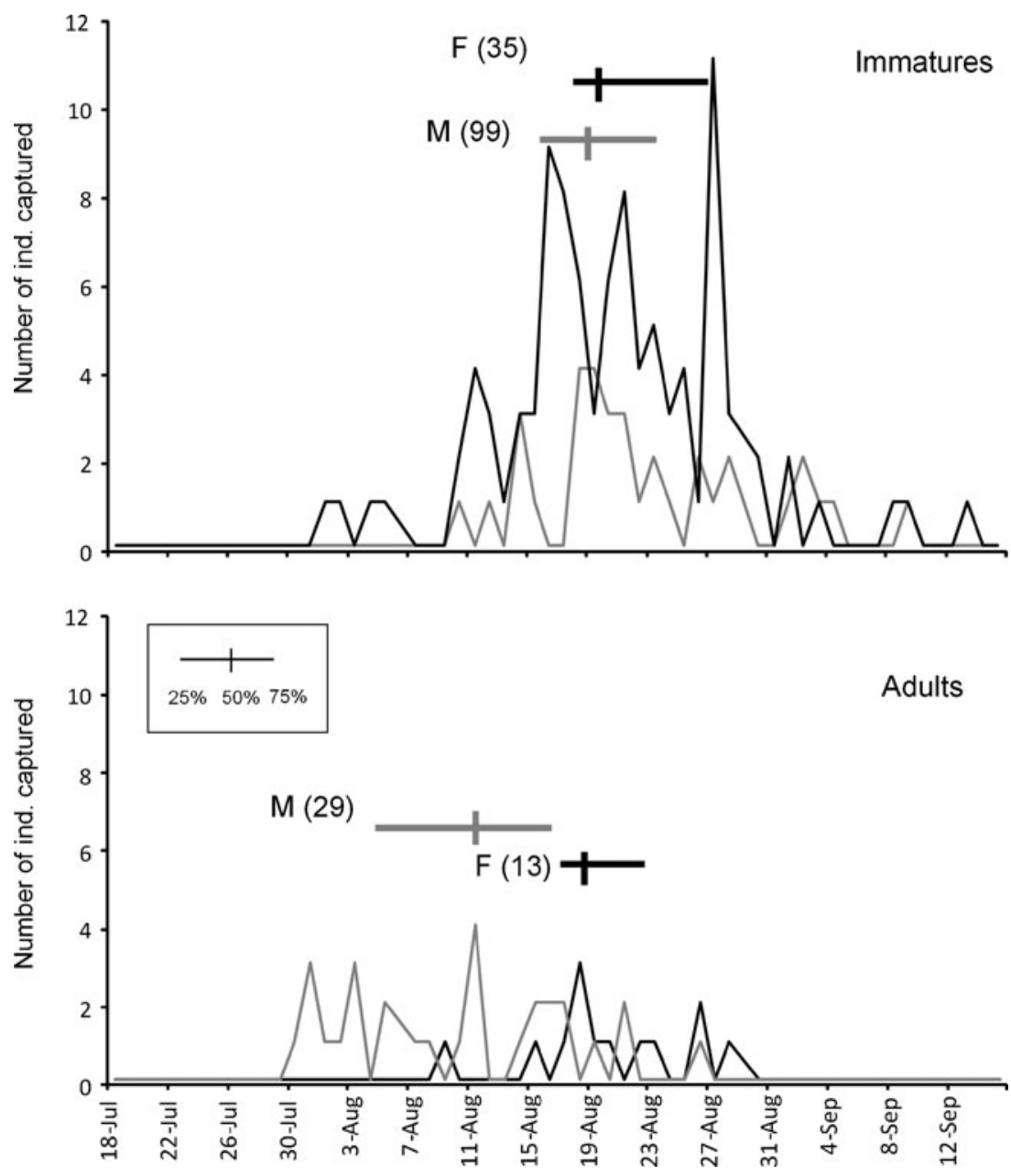
median date; $Z_{29,99}=-5.55, P<0.001$; Fig. 1$)$, whereas the timing of adult and immature females was similar (only a 2-day difference in the median date; $Z_{13,35}=-1.02, P=$ 0.31 ; Fig. 1).

Body mass was not affected by body size (ANCOVA, wing length $\left.F_{1,170}=1.72, P=0.19\right)$ or by $\operatorname{sex}\left(F_{1,170}=0.64, P=\right.$ $0.43)$. Only age was found to affect body mass, with adults being on average $6 \%$ heavier than immature birds $\left(F_{1,170}=\right.$ $14.85, P<0.001$; Fig. 2$)$. The age by sex interaction was not significant $\left(F_{1,170}=0.04, P=0.84\right)$.

Adult males had similar fat scores to adult females (median fat score for both sexes $=2 ; Z_{29,13}=0.15, P=0.88$ ); immature males and immature females also had similar fat scores (median fat score for both sexes $=2 ; Z_{99,35}=0.94, P=0.34$ ). A comparison of the fat scores across age groups revealed no differences in males $\left(Z_{29,99}=0.20, P=0.84\right)$ or females $\left(Z_{13,35}=0.59, P=0.55\right)$.

The sex ratio differed significantly from parity in both adults (chi-squared test, $\chi_{1}^{2}=4.13, P=0.04$ ) and immature birds $\left(\chi_{1}^{2}=20.91, P<0.001\right)$. The numbers of captured adult and immature males were 2.2 and 2.8 times higher, respectively, than the corresponding female age groups.

\section{Discussion}

We found sex differences in the timing of autumn migration in adult aquatic warblers, with males migrating significantly earlier than adult females. However, immature birds of both sexes migrated at a similar time. This pattern of migration, in which non-parenting adults migrate first, followed by parenting adults and young is common in ducks and

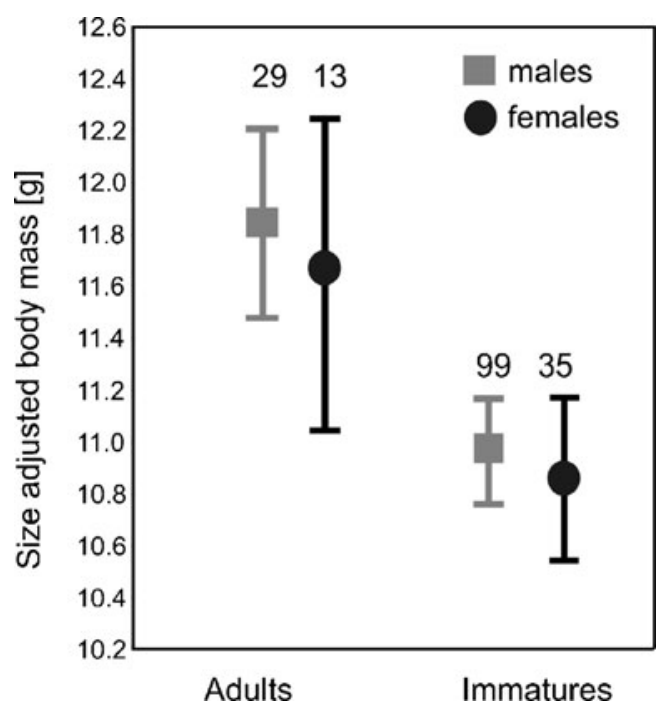

Fig. 2 Size-adjusted body mass (mean and $95 \%$ confidence intervals) in aquatic warblers of both sex and age categories during autumn migration at the Loire estuary stopover site. Numbers above the bars denote the relevant sample size shorebirds (Newton 2011). The existence of similar patterns in different taxonomic groups with similar breeding biology emphasizes the link between breeding system and migration behaviour.

Although the studied site may be considered representative (Le Nevé et al. 2011), we cannot exclude the possibility that the differential migration we observed might be specific to this particular site and season. The males may have stopped predominantly in the study site (perhaps due to tape-luring, see below), whilst the females may have stopped preferentially at another site. It is also possible that the 2011 season was an unusual breeding year with a lot of second brood attempts, this would account for the late passage of adult females and immature birds. A further examination of the autumn migration with respect to sex differences in timing, perhaps across several stopover sites, is desirable.

The frequency distribution of the capture of adult aquatic warblers of both sexes was more concentrated in time than that of immature birds, indicating differential migration of the age groups. The most likely explanation for the pattern observed is the difference in previous migration experience (e.g., Ellegren 1990). Alternatively, a differential moulting strategy may induce different migration strategy. Tegetmeyer and colleagues (2012) found some intra-specific variation in timing of moulting, which could be related to the age (or sex) groups. Finally, migration distance may be different for different age/sex groups. However, currently, there are no published data on age- or sex-based winter segregation.

We have not found any sex differences in body mass and fat scores. However, in line with reports on the aquatic warbler from other stopover sites, and on other Acrocephalus species (Julliard et al. 2006; Jakubas and Wojczulanis-Jakubas 2010), we found a tendency towards higher body masses, but not fat scores in adults compared to immature birds. This might be explained by more efficient foraging in experienced or higher social status adults. The discrepancy between the results for body mass and fat scores might be accounted for by the low resolution of the fat score system used (0-4) and/or a nonlinear relationship between fat mass and fat score (Hedenström et al. 2009).

Both adult and immature males outnumbered females in the present study. However, sex ratios in the population at nestling stage as well as in wintering areas seem to be balanced (Giessing 2002; Dyrcz et al. 2004; Vogel 2009). The most likely explanation for the biased sex ratio we observed is therefore the tape-luring used in the present study. This procedure caused a sixfold increase in the capture rate of the aquatic warbler (Julliard et al. 2006). It has also been shown that in some species (to date, these do not include the aquatic warbler), tape-luring may efficiently attract males, but not females (e.g. Lecoq and Catry 2003). Differential behaviour or habitat use might also influence the sex ratio of the captures. However, we cannot entirely rule out the 
possibility that the sex ratio observed during migration reflects a sex difference in migration routes. Females may have more frequently used an alternative, more direct migration route (e.g. via southern Europe, Salewski et al. 2013; but note that only males were investigated in this study), as they have less time after breeding for migration than males. These uncertainties indicate clearly that further studies investigating the effects of sex on the migration behaviour of aquatic warblers are needed.

Acknowledgments The study was performed under the permission given by Centre de Rechercheurs sur la Biology des Populations d'Oiseaux (C.R.B.P.O, Natural History Museum, France). The study benefited from funds from ACROLA (Association pour la Connaissance et la Recherche Ornithologique Loire et Atlantique) and partly from Juventus Plus (0470/P01/2010/70). We are very grateful to all the fieldworkers, particularly to Etienne Giraudot, Marine Boucaux and Eugene Archer. We also thank Romain Lorrilliere and the anonymous rewievers for their helpful comments on the manuscript as well as Peter Senn for the linguistic improvement.

Open Access This article is distributed under the terms of the Creative Commons Attribution License which permits any use, distribution, and reproduction in any medium, provided the original author(s) and the source are credited.

\section{References}

Aquatic Warbler Conservation Team (1999) World population, trends and threat status of the Aquatic Warbler Acrocephalus paludicola. Vogelwelt 120:65-85

Atienza JC, Pinilla J, Justribó J (2001) Migration and conservation of the Aquatic Warbler Acrocephalus paludicola in Spain. Ardeola 48: 197-208

Buchanan GM, Lachmann L, Tegetmeyer C, Oppel S, Nelson A, Flade M (2011) Identifying the potential wintering sites of the globally threatened Aquatic Warbler Acrocephalus paludicola using remote sensing. Ostrich 82:81-85

Cristol DA, Baker MB, Carbone C (1999) Differential migration revisited: latitudinal segregation by age and sex class. Curr Ornithol 15:33-88

de By RA (1990) Migration of Aquatic Warbler in Western Europe. Dutch Birding 12:165-181

Dyrcz A, Wink M, Backhaus A, Zdunek W, Leisler B, Schulze-Hagen K (2002) Correlates of multiple paternity in the Aquatic Warbler (Acrocephalus paludicola). J Ornithol 143:430-439

Dyrcz A, Sauer-Gurth H, Tkadlec E, Wink M (2004) Offspring sex ratio variation in relation to brood size and mortality in a promiscuous species: the Aquatic Warbler Acrocephalus paludicola. Ibis 146: 269-280

Ellegren H (1990) Autumn migration speed in Scandinavian Bluethroats Luscinia s. svecica. Ring Migr 11:121-131

Flade M, Diop I, Haase M, Le Nevé A, Oppel S, Tegetmeyer C, Vogel A, Salewski V (2011) Distibution, ecology and threat status of the
Aquatic warblers (Acrocephalus paludicola) wintering in West Africa. J Ornithol 152:129-140

Flade M, Lachmann L (2008) Species Action Plan for the Aquatic Warbler Acrocephalus paludicola. BirdLife International, European Commission, Cambridge

Foucher J, Boucaux M, Giraudot E, André A, Lorriliere R, Dugué H (2013) Nouveaux sites d'hivernage du Phragmite aquatique Acrocephalus paludicola. Ornithos 20:1-9

Giessing B (2002) Viele Väter für eine Brut - Vorteilhaft oder unausweichlich für das Weibchen? $\mathrm{PhD}$ thesis, University of Cologne

Griffiths R, Double MC, Orr K, Dawson RJG (1998) A DNA test to sex most birds. Mol Ecol 7:1071-1075

Hedenström A, Fagerlund T, Rosen M, Wirestam R (2009) Magnetic resonance imaging versus chemical fat extraction in a small passerine, the willow warbler Phylloscopus trochilus: a fat-score based statistical comparison. J Avian Biol 40:457-460

Jakubas D, Wojczulanis-Jakubas K (2010) Sex- and age-related differences in the timing and body condition of migrating Reed Warblers Acrocephalus scirpaceus and Sedge Warblers Acrocephalus schoenobaenus. Naturwissenschaften 97:505511

Julliard R, Bargain B, Dubos A, Jiguet F (2006) Identifying autumn migration routes for the globally threatened Aquatic Warbler Acrocephalus paludicola. Ibis 148:735-743

Kokko H (1999) Competition for early arrival in migratory birds. J Anim Ecol 68:940-950

Lecoq M, Catry P (2003) Diurnal tape-luring of wintering chiffchaffs results in samples with biased sex ratios. J Field Ornithol 74:230 232

Miguélez D, Zumalacárregui C, Fuertes B, Astiárraga H, González-Jáñez R, Roa I, de la Calzada F (2009) Habitat, phenology and biometrics of the Aquatic Warbler Acrocephalus paludicola during autumn migration through a riverine wetland in Iberia. Ring Migr 24:277279

Neto JM, Encarnação V, Fearon P (2010) Distribution, phenology and conditions of Aquatic Warblers Acrocephalus paludicola migrating through Portugal. Ardeola 57:181-189

Le Nevé A, Latraube F, Provost P, Jiguet F (2011) Synthése des captures de phragmites aquatiques en France en 2008 et 2009. In: Plan national d'actions du phragmite aquatique 2010-2014. Dreal Bretagne, $\mathrm{p} 52$

Newton I (2011) Migration within the annual cycle: species, sex and age differences. J Ornithol 152:169-185

Salewski V, Flade M, Poluda A, Kiljan G, Liechti F, Lisovski S, Hahn S (2013) An unknown migration route of the 'globally threatened' Aquatic Warbler revealed by geolocators. J Ornithol 154:549-552

Svensson L (1992) Identification guide to European passerines, 4th edn. British Trust for Ornithology, Stockholm

Tegetmeyer C, Thoma M, Arbeiter S (2012) Moult and mobility of the Aquatic Warbler Acrocephalus paludicola on the West African non-breeding grounds. J Ornithol 153:10451051

Vogel AL (2009) Genetische Bestimmung der Herkunft von im Senegal überwinternden Seggenrohrsängern. Diploma Thesis, University of Greifswald 